DOI: 10.33899/rjs.2021.167679

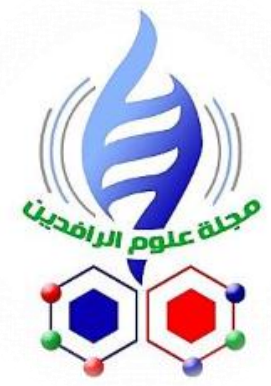

$\underline{\text { https://rsci.mosuljournals.com }}$

ISSN: 1608-9391 e-ISSN: 2664-2786

Received:20/10/2020 Accepted:8/1/2021

\section{Toxoplasma gondii: Model Manipulating by the Host Behaviour}

\author{
Musafer H. Al-Ardi \\ Al-Qadisiya General Education Directorate/ Ministry of education/ \\ Iraq \\ E-mail: Mussafir78@yahoo.com
}

\begin{abstract}
Toxoplasma gondii is an obligate intracellular parasite. Its life cycle includes two hosts, intermediate host (Mice, Rats, Birds, and Mammalians) and definitive host (feline family) which may be intermediate host, also. Toxoplasma infection exhibited variable consequences ranging from aborted to hard infections, in addition to modifications cytokines, change gene expression, and behaviour alterations.

Alteration of behaviour mechanism includes stimulating a special immune response, a change in the rate of concentration of many neurotransmitters, and a change in the concentration of some important hormones, in addition to many genetic modifications.

Many researches have established the association between Toxoplasma infection and various behaviour of the intermediate host. On the other hand, many studies regret the presence of such a relationship. Comparing the results of both studies, it can be said that the parasite infection has a clear role in the emergence of many behavior disorders that may sometimes reach schizophrenia, where the interaction of the parasite presence with the strength of the immune response and the effect of it on the concentration of neurotransmitters and some other hormones have confirmed their occurrence as confirmed the occurrence of pathological effect.
\end{abstract}

Keywords: Toxoplasma gondii; Parasite - host interaction; Dopamine; Behaviour disorder. 


\section{INTRODUCTION}

Parasites, especially those that live in two hosts, are interested in finding the suitable method for their transmission between these hosts, the most notable of these methods is to modify the behaviour of the intermediate host, these changes constitute the color, environment, or the host way of living which makes it easy prey for predators (definitive host) ( Luong et al., 2014), Changing the behaviour of the intermediate host may be intended to provide protection for the immature parasite stages (Maure et al., 2013).

There are several examples of parasite alter of the host's behaviour, for instance, Plasmodium falciparum changes the appetite of Anopheles mosquitoes to prefer feeding over nectar rather than feeding on blood to ensure that the largest amount of sugar is obtained ensuring the maturity of the parasite, while the desire to consume blood increases only when this phase has matured and tends to pass to the other host (Nyasembe et al., 2014). Horsehair worms make its host, Leucochloridium paradoxum, tend to opened and lighted places, finally, it has to drop into the water to facilitate the exit of the worm (Ponton et al., 2011).

Toxoplasma gondii can change the behaviour of an infected mouse to become more aggressive and less fearful of the cat (the definitive host) (Boillat et al., 2020), there are reports that the infection with T.gondii is responsible for schizophrenia and the craving for crime in humans (Lindová et al., 2011). Although the acute infection of the parasite is asymptomatic, the chronic stage of the infection reveals change in behaviour (Webster et al., 2013), many researches have been suggested relation between Toxoplasma and schizophrenia, in addition to, increasing of psychiatric disorders including suicide attempts when rates of exposure to Toxoplasma increase (Okusaga et al., 2011), self-directed violence (Pedersen et al., 2012), bipolar disorder (Dickerson et al., 2014), general anxiety disorders (Markovitz et al., 2015) anxiety and depressive disorder (Alvarado-Esquivel et al., 2016), obsessive-compulsive disorder (Flegr and Horacek, 2017), psychotic-like symptoms (Lindgren et al., 2018), mixed and Autism (Flegr and Horacek, 2018).

The type and severity of the disorder may be related to the location of the damage in the brain, as well as the genetic readiness of the host and the parasite strain (Lindová et al., 2011). For example, type I cannot form a cyst in the tissues or cause latent infection in the laboratory but can cause abortion, inflammatory impacts, and maybe schizophrenia (Suzuki, 2012).

\section{Mechanisms of Behaviour Manipulation}

Parasites use different mechanisms to change the host behaviour in a method that serves their survival and the continuation of the life cycle, generally, there are two ways to manipulate the behaviour : direct and indirect (Maure et al., 2013), the first being by the parasite's interference in producing special substances that change metabolism, Thus the host behaviour, the second is induced the immune system or hormonal-nervous system to reduce or increase the production of exciting substances, thus change the internal environment of the host body (Lindová et al., 2011).

Parasites always target the central nervous system, either by targeting the neurons themselves (Cabral et al., 2016) or inducing the immune system to stimulate the production of special substances that modify behaviour. In any case, methods of manipulating behaviour are by an immunological route or by modifying some neurotransmitters or by changing levels of Some of the important hormones, especially the sex hormones and testosterone (Madlaina et al., 2020).

\section{Neuron Disruption}

Neurons, in the brain, are the main target cell for $T$. gondii during central nervous system (CNS) infection, encysted bradyzoite-stage parasites are restricted to neurons (Cabral et al., 2016), it is known that, the infection hardness and the mass of cyst are determinant in the severity of the behaviour changes of infected mice (Madlaina et al., 2020).

Infection of $T$. gondii drives to the destruction of dendrites and axons structural complexity, primarily in the hippocampus and neocortex (Parlog et al., 2014). Moreover, the synaptic protein 
composition and synaptophysin were altered, especially, with a down-regulation of compounds of glutamatergic signaling as a consequence of the inflammatory milieu (Lang et al., 2018). "increased release of brain-derived neurotrophic factor (BDNF) and reversal of memory impairment due to down-regulation of pro-inflammatory myeloid cell activity via the type 2 cytokine IL- 4 produced by T cells" (Derecki et al., 2010), express receptors for multiple neurotransmitters such as GABA, dopamine, or glutamate by microglia cells (Kuhn et al., 2014).

Finally, neuronal cell will die via apoptosis or necrosis and to motor dysfunction and "cognitive by the action of interleukins (IL)-6 or IL-1 $\beta$ and tumor necrosis factor (TNF)" (Stojakovic et al., 2017).

\section{Modification of Neurotransmitters}

Neurons in the rat brain have sensory neurons that express olfactory sensory receptors that characterize the smells of predators (Hiro et al., 2016) and produce signals that travel to the amygdala or ventromedial hypothalamus $(\mathrm{VMH})$ that mediate the behaviour al response (Dewan et al., 2013), Although the role of this region of the brain in the process of selection is controversial (Lindová et al., 2011), the effect of modifying the levels of some neurotransmitters in altering behaviour remains intuitive. Assumptions of modifying behaviour by changing levels of neurotransmitters assume three reasons: The first is to increase the level of neurotransmitters by the host itself, the second is the parasite's intervention in changing these levels, and the third is because the inflammatory response is the cause of this modification (Pérez-Gómez et al., 2015).

\section{Modification of Neurotransmitters by Host}

Alsaady et al., noted that elevating dopamine levels may be to decrease the DBH expression (in noradrenergic) that gives a potential evidence for various modification notes with infection in this neurotransmitter (Johnson and Koshy, 2020). Filiano et al., showed "inhibition of neurotransmitter gamma aminobutyric acid (GABA) by Interferon- $\gamma$ (IFN- $\gamma$ ), a crucial cytokine type 1, instance, thereby affecting neuronal connectivity and social behaviour" (Filiano et al., 2016), also IFN- $\gamma$-inducible enzymes: tryptophan dioxygenase (TDO) and indoleamine-2,3-dioxygenase (IDO) accelerated tryptophan depletion (McConkey et al., 2013), decreasing of tryptophan level generates the accumulation of some harmful metabolites, particularly kynurenic acid (KYNA), an antagonist of N-metyl-D-aspartate- (NMDA) and nicotinic receptors (Campbell et al., 2014).

\section{Modification of Neurotransmitters by Parasite}

The capacity of $T$. gondii to pass the biological barriers is the main reason of the parasite progress (Harker et al., 2015). In a study, Du et al. suggested that "degradation of proteasomal by parasite rhoptry protein, T. gondii bends the NF- $\kappa \mathrm{B}$ pathway that causes p65 ubiquitination" (Du et al., 2014). In another study, assumed that "T. gondii changes lysine acetylation in astrocytes" (Bouchut et al., 2015). After there, bradyzoite cyst produces much of dopamine that can transmit into surrounding tissues (Prandovszky et al., 2011), Interestingly, T. gondii genome contains two tyrosine hydroxylase genes (AAH1 and AAH2) that could convert tyrosine to L-dopa (Johnson and Koshy, 2020).

\section{Alter Concentration of Hormones}

Alsaady et al., found suppressing of the noradrenergic system with decreasing of norepinephrine (NE) levels in vitro in neural cells of infected animals as rat and in infected human brain (Alsaady et al., 2019 ; Johnson and Koshy, 2020), as well, increased of neuroactive metabolites levels which may disturb glutamatergic and dopaminergic، and stimulates tryptophan degradation due to cytokine-mediated activation of indoleamine-2,3-dioxygenase (IDO) (Alsaady et al., 2019) and reduce the amount of serotonin[36]. As well as, a very active of genes expression Drdl and Drd2 to dopamine receptor in mice with high cyst burden (Lindová et al., 2011). 
T. gondii elevates Testosterone concentration in patients (Madlaina et al., 2020), just male (Johnson and Koshy, 2020), Giltay et al. explained that "Testosterone able to relieve depression and anxiety, and actives Pure thinking", decreasing of this hormone levels were noted also in female with anxiety and depressive disorders (Giltay et al., 2012), "increase the expression of Testosterone receptors in the testes which regulates the synthesis of testosterone" (Lim et al., 2013).

\section{Immunity Reaction}

The overexpression level of interferon-gamma $(I F N-\gamma)$, interleukin- $12 \mathrm{~b}(I L-12 b)$, tumor necrosis factor (TNF) [6] and IL-12/IL-23" (Hiro et al., 2016), interleukin (IL)-6, or IL-1 $\beta$ (Habbas et al., 2015), as well as, the nitric oxide synthase locates downstream effector of IFN- $\gamma$, therefor the higher production of (Nos2) can lead to neuronal toxicity also, through nitrosative and oxidative stress, instead of protection against the parasite (Lindová et al., 2011).

The parasite attempts to balance the slow multiplication and excessive virulence by modifying some host immune mechanisms, especially dense granule family (GRA) members (Olias et al., 2016), by the analytical action of ASP5 by the cologne system in the parasite (Curt-Varesano et al., 2016).

\section{Genomic Modification \\ Modification of Host Genes:}

Several phenomena of gene modification occur after Toxoplasma infection including modification of many cytokines, and increasing their concentration (Abdul-Lateef et al., 2012), dopamine receptor gene and dense granule family (GRA) inhibition were inhibition (Lindová et al., 2011), "gene expression down-regulation of dopamine -hydroxylase (DBH) (encoding enzyme that produces norepinephrine from dopamine) and observed down regulation in infected brain tissue and in vitro, with a significant difference in male" (Donley et al., 2016).

Chronic T. gondii infection Genetic control the resistance and susceptibility in the brain of both mice and humans was formed, such as, the $L d$ gene in mice which is located in the D region of the major histocompatibility complex $(\mathrm{H}-2)$. In humans, HLA-DQ3 is a genetic marker of susceptibility in congenitally infected infants and AIDS patients, whereas DQ1 is a genetic marker of resistance. Because the $L d$ gene in mice and the $H L A-D Q$ genes in humans are part of the major histocompatibility complex that regulates the immune responses (Donley et al., 2016).

\section{Modification of Parasite Genes}

T. gondii secrets effector molecules that modulate the host gene expression (Adamo and Webster, 2013; Fond et al., 2013) or cause post-translational modification such as protein residues acetylation in glial cells and neurons (Bouchut et al., 2015). Qing Tao and his colleagues indicated the presence of 14 antigens that contributed to the parasite invasion and metabolism, and confirmed the hypothesis that say that the calmodulin $(\mathrm{CaM})$ antigen is important in the pathogenesis of the parasite and destroy the host neuron cells (Qing et al., 2014). It is possible that the action of these antigens is indirect by triggering an immune response that affects dopamine concentrations (Flegr, 2007). Other studies have indicated the parasite's ability to modify genes that stimulate host cells to rest cell cycle at the M and G2 stages (Brunet et al., 2008; Molestina et al., 2008). Some studies Overexpression of ASP5 gene (protoanalytic GRA) (Lim et al., 2013), and tyrosine hydroxylase AAH1 and AAH2 that Increase L-dopamine level(Johnson and Koshy, 2020). Finally, several studies confirmed relationship between parasite and the development of infection with the strain, (Xiao et al., 2018) as it indicated the association of the strain II with a number of schizophrenia cases and a host behavioral modulation (Carruthers and Suzuki, 2018). 


\section{DISCUSSION}

Although many studies have attempted to correlate infection with T. gondii and manipulation of behaviour after infection (Ling et al., 2011; Okusaga et al., 2011; Del Grande et al., 2017), there is still no conclusive evidence that alters in behaviour caused by parasite infection only (Dickerson et al., 2018), there are many conditions that may cause behaviour modification such as environmental conditions (Sih et al., 2004), and genetic predisposition in people (Bell, 2005), in addition to the parasite strain (Torrey et al., 2007).

All immune, genetic, hormonal and other variations represent a natural reaction to the parasite's entry into the host (Boillat et al., 2020), the parasite has many ways to stimulate the immune system or inhibit it to survive the parasite (Okusaga et al., 2011), for example, the parasite is trying to transform to the latent phase (bradyzoite) after reaching the central nervous system (Cabral et al., 2016), the presence of the latent phase and the chain of the immune response towards it lead to necrosis or death of neurons, the reason for their occurrence may be due to the influence of these cells by the substances produced by the parasite, as well as, by the lack of food and oxygen resulting from disturbances in the blood vessels, or perhaps necrosis. The result in the cells and brain tissue that they are affected by the case-specific enzymes of the protein present in the white blood cells, especially the rates that increase their infiltration as a response to inflammatory reactions in the cerebellum, as well as some immune reactions, and if they are protective, they may cause necrosis or cells death by macrophages and mononucleosis (Fischer et al., 1997).

Many alterations occur at the level of neurotransmitters after the chronic infection of the parasite, as many studies have indicated a high concentration of dopamine after infection (AL-Hadad et al., 2019), the reason may be attributed to defects in the metabolism of catecholamine (Martynowicz et al., 2019), or due to the parasite has two important enzymes, phenylalanine hydroxylase and tyrosine hydroxylase, which together act to increase the level of dopamine by stimulating the metabolism of phenylalanine and tyrosine (Prandovszky et al., 2011).

T. gondii can synthesize the sphingolipids (Azzouz et al., 2002), but they obtain phospholipids and fatty acids from the host or by salvage (Charron and Sibley, 2002), this may explain the downregulate that occurs in the metabolism of many compounds made from fats, such as arachidonic acid, steroids, and glycerophospholipid, which directly enter the functions of the neuron (Ma et al., 2019), in addition to many other functions such as Antioxidants, apoptosis, and others (Farooqui et al., 2000). Also, the products of the steroid hormone metabolites are identified as gamma-aminobutyric acid (GABA) receptor. Besides, GABA depends on arachidonic acid in its formation (Ma et al., 2019).

The level rise of some sex hormones in the event of infection with the parasite may not be caused by the host only, but the parasite may get involved in this (Abdul-Lateef et al., 2012), the increase in the progesterone hormone, for example, causes inhibition of NK cells, macrophage and $\mathrm{T}$ cells, and reduces the production of NO (McKay and Cidlowski, 1999), which survive the parasite (Lori et al., 2002), and vice versa, weak immunity stimulates the increase of the hormone (Flegr, 2013), two hypotheses explain the increase testosterone hormone: the first assumes that the increase is a defensive process performed by the host when suppressing immunity, the second assumes that the parasite contributes to increasing the concentration of the hormone to resist the immune force and survive (Roberts et al., 2001).

\section{CONCLUSION}

From all we see that, Toxoplasma, like other parasites, has the ways to survive and ensure transmission between hosts, thus, alter the host behaviour to serve the parasite. These changes include stimulating a moderate immune response, an altering in the level of neurotransmitters and some primary hormones, in addition to, modifying the gene expression of the host. The relationship between infection with the parasite and the feeling of hysterical outbursts of anger, abandonment of over-impulsion fear, in addition to neurological disorders such as bipolar disorder and the urge to 
commit suicide. All these effects and their association with the infection confirm the parasite's association with host behavior disorders.

\section{REFERENCES}

Abdul-Lateef, H.I.; Al-Najar, S.A.; Abul Majeed, N.G. (2012). The levels of IFN-, IL- 12 And Testosterone Hormone in Persons with Asymptomatic Toxoplasmosis. J. Fac. Med. Baghdad., 54(1), 79-82.

Adamo, S.A.; Webster, J.P. (2013). Neural parasitology: How parasites manipulate host behaviour. J. Exp. Biol., 216, 1-2.

AL-Hadad, M.T.S.; Kadhim, R.A.; Al-Rubaye, A.F. (2019). Effect of chronic toxoplasmosis on levels of some neurotransmitters (Dopamine, Adrenaline, and Noradrenaline) in human serum J. Pharm. Sci. and Res., 11(2), 402-405.

Alsaady, I.; Tedford, E.; Alsaad, M.; Bristow, G.; Kohli, S.; Murray, M.; Reeves, M.; Vijayabaskar, M.S.; Clapcote, S.J.; Wastling, J.; McConkey, G.A. (2019). Down regulation of the Central Noradrenergic System by Toxoplasma gondii Infection. Infect. Immun., 87, 789-18.

Alvarado-Esquivel, C.; Sanchez-Anguiano, L.; Hernandez-Tinoco, J.; Berumen-Segovia, L.; Torres-Prieto, Y.E.; Estrada-Martinez, S.; Perez-Alamos, A.R.; Ortiz-Jurado, M.N.; Molotla-de-Leon, G.; Garcia, I.B.; Rabago-Sanchez, E.; Liesenfeld, O. (2002). Toxoplasma gondii infection and mixed anxiety and depressive disorder: a case-control seroprevalence study in Durango, Mexico. J. Clin. Med. Res., 8(7), 519-523.

Azzouz, N.; Rauscher, B.; Gerold, P.; Cesbron-Delauw, M.F.; Dubremetz, J.F.; Schwarz, R.T. (2002). Evidence for de novo sphingolipid biosynthesis in Toxoplasma gondii. Intl. J. Parasitol., 32, 677-684.

Bell, A.M. (2005). Behavioural differences between individuals and two populations of stickleback (Gasterosteus aculeatus). J. Evol. Biol., 18(2), 464-473.

Boillat, M.; Hammoudi, P.M.; Dogga, S.K.; Pagès, S.; Goubran, M.; Rodriguez, I.; SoldatiFavre, D. (2020). Neuroinflammation associated a specific manipulation of mouse predator fear by Toxoplasma gondii. Cell Rep., 30(2), 320-334.

Bouchut, A.; Chawla, A.R.; Jeffers, V.; Hudmon, A.; Sullivan, J.R. (2015). Proteome-wide lysine acetylation in cortical astrocytes and alterations that occur during infection with brain parasite Toxoplasma gondii. PLoS. One.,10(3), 0117966.

Brunet, J.; Pfaff, A.W.; Abidi, A.; Unoki, M.; Nakamura, Y.; Guinard, M. (2008). Toxoplasma gondii exploits UHRF1 and induces host cell cycle arrest at G2 to enable its proliferation.

Cell Microbiol., 10, 908-20.

Cabral, C.M.; Tuladhar, S.; Dietrich, H.K.; Nguyen, E.; MacDonald, W.R.; Trivedi, T.; Devineni, A.; Koshy, A.A. (2016). Neurons are the primary target cell for the brain-tropic intracellular parasite Toxoplasma gondii. PLoS. Pathog., 12(2), e1005447.

Campbell, B.M.; Charych, E.; Lee, A.W.; Moller, T. (2014). Kynurenines in CNS disease: Regulation by inflammatory cytokines. Front Neurosci., 8,12.

Carruthers, V.B.; Suzuki, Y. (2018). Effects of Toxoplasma gondii infection on the brain. Schizophr Bull., 33(3),745- 751.

Charron, A.J.; Sibley, L.D. (2002). Host cells, mobilizable lipid resources for the intracellular parasite Toxoplasma gondii. J. Cell Sci., 115(15), 3049-3059.

Curt-Varesano, A.; Braun, L.; Ranquet, C.; Hakimi, M.A.; Bougdour, A. (2016). The aspartyl protease TgASP5 mediates the export of the Toxoplasma GRA16 and GRA24 effectors into host cells. Cell Microbiol.,18(2), 151-167.

Del Grande, C.; Galli, L.; Schiavi, E.; Dell'Osso, L.; Bruschi F.(2017). Is Toxoplasma gondii a trigger of bipolar disorder? Pathogens., 6(1), 3. 
Derecki, N.C.; Cardani, A.N.; Yang, C.H.; Quinnies, K.M.; Crihfield, A.; Lynch, K.R. Kipnis, J. (2010). Regulation of learning and memory by meningeal immunity: a key role for IL-4. $J$. Exp. Med., 207(5),1067-80.

Dewan, A.; Pacifico, R.; Zhan, R.; Rinberg, D.; Bozza, T. (2013). Non-redundant coding of aversive odors in the main olfactory pathway. Nature, 497(7450), 486-489.

Dickerson, F.; Origoni, A.; Schweinfurth, L.A.; Stallings, C.; Savage, C.L.; Sweeney, K.; Katsafanas, E.; Wilcox, H.C.; Khushalani, S.; Yolken, R. (2018). Clinical and serological predictors of suicide in schizophrenia and major mood disorders. J. Nerv. Ment. Dis., 206(3), 173-178.

Dickerson, F.; Stallings, C.; Origoni, A.; Vaughan, C.; Katsafanas, E.; Khushalani, S.; Yolken, R. (2014). Antibodies to Toxoplasma gondii in individuals with mania. Bipolar Disord.,16(2),129-136.

Donley, D.W.; Olson, A.R.; Raisbeck, M.F.; Fox, J.H.; Gigley, J.P. (2016). Huntingtons Disease Mice Infected with Toxoplasma gondii Demonstrate Early Kynurenine Pathway Activation, Altered CD8+ T-Cell Responses, and Premature Mortality. PLoS. One, 11(9), $\mathrm{e} 0162404$.

Du, J.; An, R.; Chen, L.; Shen, Y.; Chen, Y.; Cheng, L.; Jiang, Z.; Zhang, A.; Yu, L.; Chu, D.; Shen, Y.; Luo, Q.; Chen, H.; Wan, L.; Li, M.; Xu, X.; Shen, J. (2014). Toxoplasma gondii virulence factor ROP18 inhibits the host NF-kappaB pathway by promoting p65 degradation. J. Bio. Chem., 289(18),12578-12592.

Farooqui, A.A.; Horrocks, L.A.; Farooqui, T. (2000). Glycerophospholipids in brain: their metabolism, incorporation into membranes, functions, and involvement in neurological disorders. Chem. Phys. Lipids, 106(1), 1-29.

Filiano, A.J.; Xu, Y.; Tustison, N.J.; Marsh, R.L.; Baker, W.; Smirnov, I. (2016). Unexpected role of interferon- $\gamma$ in regulating neuronal connectivity and social behaviour. Nature, 535(6712), 425-629.

Fischer, H.G.; Nitzgen, B.; Reichmann, G.; GroB, U.; Hadding, U. (1997). Cytokines responses induced by Toxoplasma gondii inastrocytes and microglial cells. Eur. J. Immunol., 27(6), 1534-1548.

Flegr, J.; Horáček, J. (2017). Toxoplasma-infected subjects report an Obsessive-Compulsive Disorder diagnosis more often and score higher in Obsessive-Compulsive Inventory. Eur. Psychiatry. J. Associat. Eur. Psychiatr., 40, 82-87..

Flegr, J.; Horacek, J. (2018). Toxoplasmosis, but not borreliosis, is associated with psychiatric disorders and symptoms. Schizophr. Res., 197, 603-604.

Flegr, J. (2007). Effects of toxoplasma on human behavior. Schizophrenia bulletin, 33(3), 757-760.

Flegr J. (2013). Influence of latent Toxoplasma infection on human personality, physiology and morphology: prosandcons of the Toxoplasma-human model in studying the manipulation hypothesis. J. Exp. Biol., 216,127-133.

Fond, G.; Capdevielle, D.; Macgregor, A.; Attal, J.; Larue, A.; Brittner, M.; Ducasse, D. and Boulenger, J. P. (2013). Toxoplasma gondii: un rôle potential dans la genèse de troubles psychiatriques. Une revue systématique de la littérature [Toxoplasma gondii: a potential role in the genesis of psychiatric disorders]. L'Encephale, 39(1), 38-43.

Giltay, E.J.; Enter, D.; Zitman, F. G.; Penninx, B. W.; van Pelt, J.; Spinhoven, P.; Roelofs, K. (2012). Salivary testosterone: associations with depression, anxiety disorders, and antidepressant use in a large cohort study. J. Psychosom. Research, 72(3), 205-213.

Habbas, S.; Santello, M.; Becker, D.; Stubbe, H.; Zappia, G.; Liaudet, N.; Klaus, F. R.; Kollias, G.; Fontana, A.; Pryce, C. R.; Suter, T.; Volterra, A. (2015). Neuroinflammatory TNF $\alpha$ impairs memory via astrocyte signaling. Cell, 163(7), 1730-1741.

Harker, K.S.; Ueno, N.; Lodoen, M.B. (2015). Toxoplasma gondii dissemination: A parasite's journey through the infected host. Parasite Immunol., 37(3),141-149. 
Hiro, M.O.; Fidan, F.A.; Aeshah, N.I. (2016). Some hormonal assay in toxoplasma infected university student. Kirkuk University J. / Scientif. Studies (KUJSS), 11(3), 66-80.

Johnson, H.J.; Koshy, A.A. (2020). Latent toxoplasmosis effects on rodents and humans: how much is real and how much are mediahype?. M. Bio., 11, e02164-19.

Kuhn, S. A., van Landeghem, F. K., Zacharias, R., Färber, K., Rappert, A., Pavlovic, S.; Hoffmann, A.; Nolte, C.; Kettenmann, H. (2004). Microglia express GABA(B) receptors to modulate interleukin release. Molecular and Cellular Neurosciences, 25(2), 312-322.

Lang, D.; Björn, H..; Marco van, S.; Lorena, H.; Leonora, M. K.; Rodrigo, Rainer, H.; Frank, P.; Dirk, K.; Lothar, M.; Eckart, J.; Gundelfinger, D.; Smalla K.; Dunay I. R. (2015). Chronic Toxoplasma infection is associated with distinct alterations in the synaptic protein composition. J. Neuroinflammat., 15(1), 216.

Lim, A.; Kumar, V.; Hari Dass, S.A.; Vyas, A. (2013). Toxoplasma gondii infection enhances testicular steroidogenesis in rats. Mol. Ecol., 22, 102-110.

Lindgren, M.; Torniainen-Holm, M.; Härkänen, T.; Dickerson, F.; Yolken, R.H.; Suvisaari, J. (2018). The association between toxoplasma and the psychosis continuum in a general population setting. Schizophr Res., 193, 329-335.

Lindová, J.; Př́íplatová, L.; Flegr, J. (2012). Higher extraversion and lower conscientiousness in humans infected with toxoplasma / lindová. Eur. J. Personal./ Wiley Online Library, Eur. J. Personal., 26 (3), 285-291.

Ling, V.J.; Lester, D.; Mortensen, P.B.; Langenberg, P.W.; Postolache, T. (2011). Toxoplasma gondii seropositivity and suicide rates in women. J. Nervous and Mental Disease, 199(7), 440-444.

Lori, C.; Kenneth, H.E.; Martha, E.W.; Imtiaz, A. (2002). CD8 + T-cell immunity against Toxoplasma gondiican be induced but not maintained in mice lacking conventional CD4+ T cells. Infect. Immunol., 70, 434-443.

Luong, L.; Grear, D.; Hudson P. (2014). Manipulation of host-resource dynamics impacts transmission of trophic parasites. Internat. J. Parasitol., 44(10), 737-742.

Ma, J.; He, J.; Hou, J.; Zhou, C.; Zhang, F.; Elsheikha H. M.; Zho X. (2019). Metabolomic signature of mouse cerebral cortex following Toxoplasma ondii infection. Parasites Vectors, 12, 373.

Madlaina, B.; Pierre-Mehdi, H.; Sunil Kumar, D.; Stéphane, P.; Maged, G.; Ivan, R.; Dominique, S. (2020). Neuroinflammation-Associated A specific Manipulation of Mouse Predator Fear by Toxoplasma gondii. Cell Rep., 30(2), 320-334.

Markovitz, A. A.; Simanek, A. M.; Yolken, R. H.; Galea, S.; Koenen, K. C.; Chen, S.; Aiello, A. E. (2015). Toxoplasma gondii and anxiety disorders in a community-based sample. Brain Behavior and Immunity, 43, 192-197.

Maure, F.; Brodeur, J.A.; Doyon, J.; Thomas, F. (2013). Bodyguard manipulation in a multipredator context: Different processes, same effect. Behaviour. Process., 99, 81-86.

McConkey, G.A.; Martin, H.L.; Bristow, G.C.; Webster, J.P. (2013). Toxoplasma gondii infection location, location, location? J. Exp. Biol., 216,113-119.

McKay, L.I.; Cidlowski, J.A. (1999). Molecular control of immune/inflammatory responses: interactions between nuclear factor- B and steroid receptor-signaling pathways. Endocr. Rev., 20(2), 435-459.

Molestina, R.E.; El-Guendy, N.; Sinai, A.P. (2008). Infection with Toxoplasma gondii results in dysregulation of the host cell cycle. Cell Microbiol..10,1153-65.

Nyasembe, V.O.; Peter, E.A.; Sawaa, P.; James H.; Tumlinsonc, C.B.; Baldwyn T. (2014). Plasmodium falciparum Infection Increases Anopheles gambiae Attraction to Nectar Sources and Sugar Uptake. Current Biol., 24(2), 217-21. 
Okusaga, O.; Langenberg, P.; Sleemi, A.; Vaswani, D.; Giegling, I.; Hartmann, A.M.; Konte, B.; Friedl, M.; Groer, M.W.; Yolken, R. H.; Rujescu, D.; Postolache, T.T. (2011). Toxoplasma gondii antibody titers and history of suicide attempts in patients with schizophrenia. Schizophrenia Research, 133(1-3), 150-155.

Olias, P.; Etheridge, R.D.; Zhang, Y.; Holtzman, M.J.; Sibley, L.D. (2016). Toxoplasma effector recruits the $\mathrm{Mi}-2 / \mathrm{NuRD}$ complex to repress STAT1 transcription and block IFN- $\gamma-$ dependent gene expression. Cell Host Microbe., 20,72-82

Parlog, A.; Harsan, L.A.; Zagrebelsky, M.; Weller, M.; von Elverfeldt, D.; Mawrin, C.; Korte, M.;Dunay, I.R. (2014). Chronic murine toxoplasmosis is defined by subtle changes in neuronal connectivity. Disease Models Mechan., 7(4), 459-469.

Pedersen, M.G.; Mortensen, PB.; Norgaard-Pedersen, B.; Postolache, T.T. (2012). Toxoplasma gondii infection and self-directed violence in mothers. Arch. Gen. Psychiatry, 69,11231130.

Pérez-Gómez, A.; Bleymehl, K.; Stein, B.; Pyrski, M.; Birnbaumer, L.; Munger, S.D.; LeindersZufall, T.; Zufall, F.; Chamero, P. (2015). Innate Predator Odor Aversion Driven by Parallel Olfactory Subsystems that Converge in the Ventro-medial Hypothalamus. Curr. Biol., 25,1340-1346.

Ponton, F.; Otálora-Luna, F.; Lefèvre, T.; Guerin, P. M.; Lebarbenchon, C.; Duneau, D.; Biron, D. G.; Thomas, F. (2011). Water-seeking behaviour in worm-infected crickets and reversibility of parasitic manipulation. Behav. Ecol., 22 (2), 392-400.

Prandovszky, E.; Gaskell, E.; Martin, H.; Dubey, J.P.; Webster, J.P.; McConkey, G.A. (2011). The neurotropic parasite Toxoplasma gondii increases dopamine metabolism. PLoS ONE, 6(2), e23866.

Qing, T.; Jiang, X.; Yifan, W.; Kun, F.; Nizhi, Li.; Min, Hu.; Yanqin, Z.; J. Zhao (2014). Identification of Genes Expressed During Toxoplasma gondii Infection by in Vivo-Induced Antigen Technology (IVIAT) with Positive Porcine Sera. J. Parasitol., 100(4), 470-479.

Roberts, C.W.; Walker, W.; Alexander J. (2001). Sex-associated hormones and immunity to protozoan parasites. Clin. Microbiol. Rev.,14, 476-488.

Sih, A.; Bell, A.M.; Johnson, J.C.; Ziemba, R.E. (2004). Behavioral syndromes: an integrative overiew. Q. Rev. Biol., 79, 241-277.

Soleymani, E.; Faizi, F.; Heidarimoghadam, R.; Davoodi, L.; Mohammadi, Y. (2020). Association of T. gondii infection with suicide: a systematic review and meta-analysis. BMC Public Health, 20(1) 766.

Stojakovic, A.; Paz-Filho, G.; Arcos-Burgos, M.; Licinio, J.; Wong, M.L.; Mastronardi, C.A. (2017). Role of the IL-1 pathway in dopaminergic neurodegeneration and decreased voluntary movement. Mol. Neurobiol., 54, 4486-95.

Suzuki, Y. (2012). Host resistance in the brain against Toxoplasma gondii. J. Infect. Dis., 185(1), $58-65$.

Torrey, E.F.; Bartko, J.J.; Lun, Z.R.; Yolken, R.H. (2007). Antibodies to Toxoplasma gondii in patients with schizophrenia: A meta-analysis. Schizophrenia Bulletin., 33(3),729-736.

Webster, J.P.; Kaushik, M.; Bristow, G.C.; McConkey, G.A. (2013). Toxoplasma gondii infection from predation to schizophrenia: can animal behaviour help us understand human behaviour? J. Exp. Biol., 216, 99-112.

Xiao, J.; Prandovszky, E.; Kannan, G.; Pletnikov, M.V.; Dickerson, F.; Severance, E.G.; Yolken, R.H. (2018). Toxoplasma gondii: Biological Parameters of the Connection to Schizophrenia. Schizophrenia bulletin, 44(5), 983-992. 


\section{المقوسة الغوندية أنموذج التلاعب بسلوك المضيف}

\section{الملخص}

المقوسة الغوندية طفيلي داخلي اجباري التطفل، تتضمن دورة حياته اثثين من المضائف مضيف وسطي يشمل الفئران و

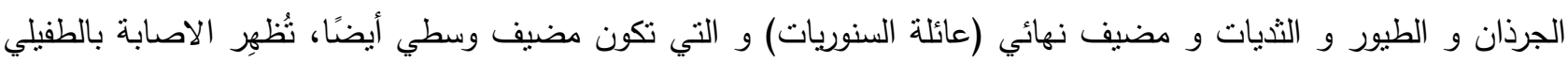
نتائج متغايرة تتراوح بين الإجهاض و الاصابات الحادة بالإضافة إلى تعديلات في السايتوكاينات والتعبير الجيني والسلوك.

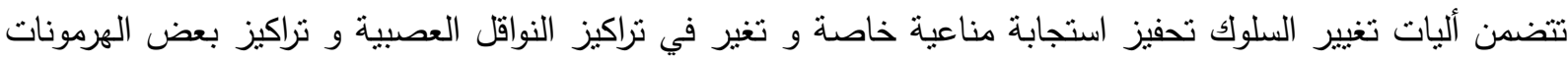
المهمة بالإضافة إلى تعديل العديد من الجينات.

على الرغم من إن الكثير من الدراسات اكدت أثز الاصابة بالمقوسة الغوندية في تغاير سلوك المضائف المتوسطة، إلا إن إن إنائ

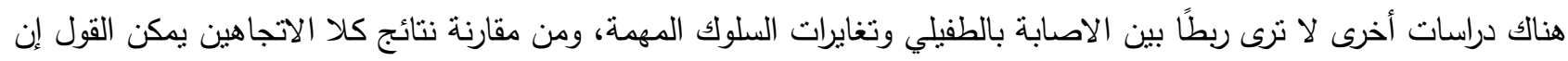
للإصابة بطفيلي المقوسة الغوندية دور واضح في ظهور العديد من اضطرابات السلوك قد تصل احيانًا إلى انفصام الشخصية،

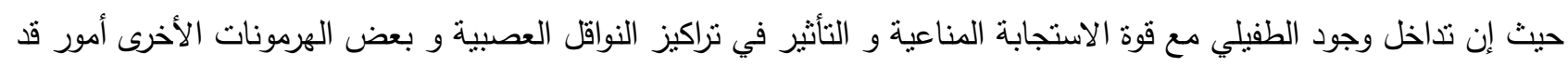
أُكد حدوثها كما أُكد حدوث الاثر المرضي و التخريب النسيجي بسبب الطفيلي. الكلمات الدالة: المقوسة الغوندية، تفاعل الطفيلي - المضيف، اضطراب السلوك، دوبامين. 